\title{
Finaneial MTarket
}

Central European Review of Economics \& Finance

Vol. 23, No. 1 (2018), pp. 59-68

DOI: $10.24136 /$ ceref.2018.005

Received: 12 December 2017. Accepted: 22 January 2018

Grigorios GIKAS ${ }^{1}$, Alina HYZ ${ }^{2}$, Periklis TAGKAS ${ }^{3}$

\section{ABOLISHING CASH IN EUROPE: THE BENEFITS AND DRAWBACKS OF ELECTRONIC TRANSACTIONS}

Many proposals favouring cash abolition have emerged over the past few years. Their economic and social impact has not yet been analysed in depth. This paper aims to present the evolution of the means of payment during the last decades and to analyse the issue of cash abolition in European economies. The creation of a cashless economy would bring benefits, such as efficiency increase, as well as problems: the disturbance of money supply, instability of the foreign exchange rate, and so on.

The paper discusses the reasons and arguments expressed by supporters and opponents of cash abolition and focuses on possible consequences, from the economic point of view. The advantages, disadvantages, benefits and costs associated with the possibility of removing cash from the economy are also described. Finally, a possible scenario for the future is analysed.

JEL Classification Codes: E44, E50.

Keywords: Monetary Policy, Financial Markets.

\section{Introduction}

During the last decades there is a tendency to limit the use of cash (banknotes and coins) in daily transactions ${ }^{4}$. This tendency comes from two basic sources. The first is related to technological progress. Technological advances mean that there are now several electronic alternatives in areas where cash has traditionally been used. The second

\footnotetext{
${ }^{1}$ Professor, Department of Accounting and Finance, Technological Educational Institute of Epirus and Postgraduate Programme on Banking, Hellenic Open University.

${ }^{2}$ Professor, Department of Accounting and Finance, Piraeus University of Applied Sciences and Postgraduate Programme on Banking, Hellenic Open University.

${ }^{3}$ Professor, Department of Business Administration, Technological Educational Institute of Epirus.

${ }^{4}$ The term „cash" in this paper refers only to physical banknotes and coins issued by the central bank.
} 
one is connected with legal restrictions introduced in different countries which prohibit cash payments in specific transactions. Maximum limits on cash transactions already exist in most European countries, and the general trend is downward. For example, in 2016 Spain joined France in placing 1,000 maximum on cash transactions between consumers and businesses. In Greece, paragraph 3 of Article 20 of Law 3842/2010, as amended by paragraph 2 of Article 69 of Law 4446/2016, stipulated that from 22 Dec. 2015 onwards the trading threshold would be reduced from 1,500 to 500 euro, above which transactions between individuals and businesses (for the sale of goods or the provision of services) should be carried out exclusively through the use of card-based payment instruments or other electronic means of payment (as, for instance, electronic funds transfer, use of an electronic wallet, etc.). In the second case, the state prohibits by law cash payments which it has itself declared as an unrestricted, legitimate means of payment. It is possible that in future citizens without a bank account and a credit card may not be able to drive a car, go out for a meal or go shopping.

All the above may drive us to abolish cash completely from our society. Judging by the number of news items on the topic of payments and activities taken by the governments of many countries, one might conclude that the so called "cashless society" is the only way forward, and cash has lost its role in our modern society.

This paper aims to present the evolution of the means of payment during the last decades and to analyse the issue of cash abolition in European economies. We try to find the answer to the following questions: What is the future of cash? What kind of benefits would the creation of a cashless economy bring? Are there any problems connected to cash abolition?

\section{Cash and non cash transactions}

Cash is defined as ready money and cash payment transactions consist of banknotes and coins. Cash is legal tender with a unique status among all other payment instruments. Cash has a number of special attributes comparing to non cash payment instruments. Banknotes and coins are bearer certificates. They can be used by anyone who is in possession of them without leaving electronic trails. The anonymity in cash transactions caused by payment in cash can be motivated by a wish to protect one's private life. On the other side, the anonymity of cash also means that it can be used for illegal purposes. Cash is physical, which makes it simple and easy to understand. This property is of special importance for older people and children. Cash, in contrast to other means of payments, does not require any technical infrastructure in the payment situation. Cash transactions mean certainty of receiving payment. When payments are made by cash, funds are settled and received during the transaction. It increases liquidity, since transferred funds are immediately available. Usually, cash is a widely accepted means of payment in all parts of society. It is also a fast method of 
payment since the processing time is very short. It requires the presence of two parts of transaction at the same location. Cash, however, is costly since it must be produced, transported and stored. In addition, cash exposes people to the risk of theft, as well as the risk of human error during the transaction. Different security measures such as cameras, security guards, secure storage are also indirect costs associated with using cash. Cash is also seen as a labour intensive form of payment since it requires for example delivery of cash to the financial institution. There is also some kind of opportunity cost in using cash transactions, resulting from not earning interest on cash holdings in registers or while it is in transit. Using cash transactions enables budget management and limits consumption to the amount of money which people possess at the moment of transaction. Some of the above properties apply only to cash and some are common with electronic payment solutions.

Cash transaction volumes are very difficult to establish mainly due to their anonymous nature. Figure 1 shows the distribution across all payment instruments (including cash and non-cash) per country. According to the estimates in 20 out of $28 \mathrm{EU}$ countries, cash represents over $50 \%$ of all payment transactions and varies widely across member states (G4S, 2016). Relative cash usage is highest in southern and/or eastern countries, with the first 12 places occupied by countries from those regions. Relative cash usage is lowest in Northern and/or Western countries, with the bottom 6 places occupied by countries from those regions. Countries like Greece, Bulgaria and Romania almost solely pay by means of cash. In Denmark and Sweden cards are most used, while e-money purchase transactions are most prevalent in Luxembourg. For access to electronic payments, it is reported that for the EU28 as a whole $86 \%$ of the population (age $>15$ ) holds at least one bank account at a formal Financial Institution. The EC reports also that on Use of Internet and Integration of Digital Technology (including e-Commerce, cloud and online services) just over $78 \%$ of the European population has access to the Internet, more than half (57\%) of EU Internet users use online banking and close to two-thirds (63\%) do their shopping online (Kruger, Seitz, 2016).

Examining the time trends, non-cash transaction volumes, especially card transactions, seem to grow faster, resulting in a diminishing share of cash in the total transaction volume. 


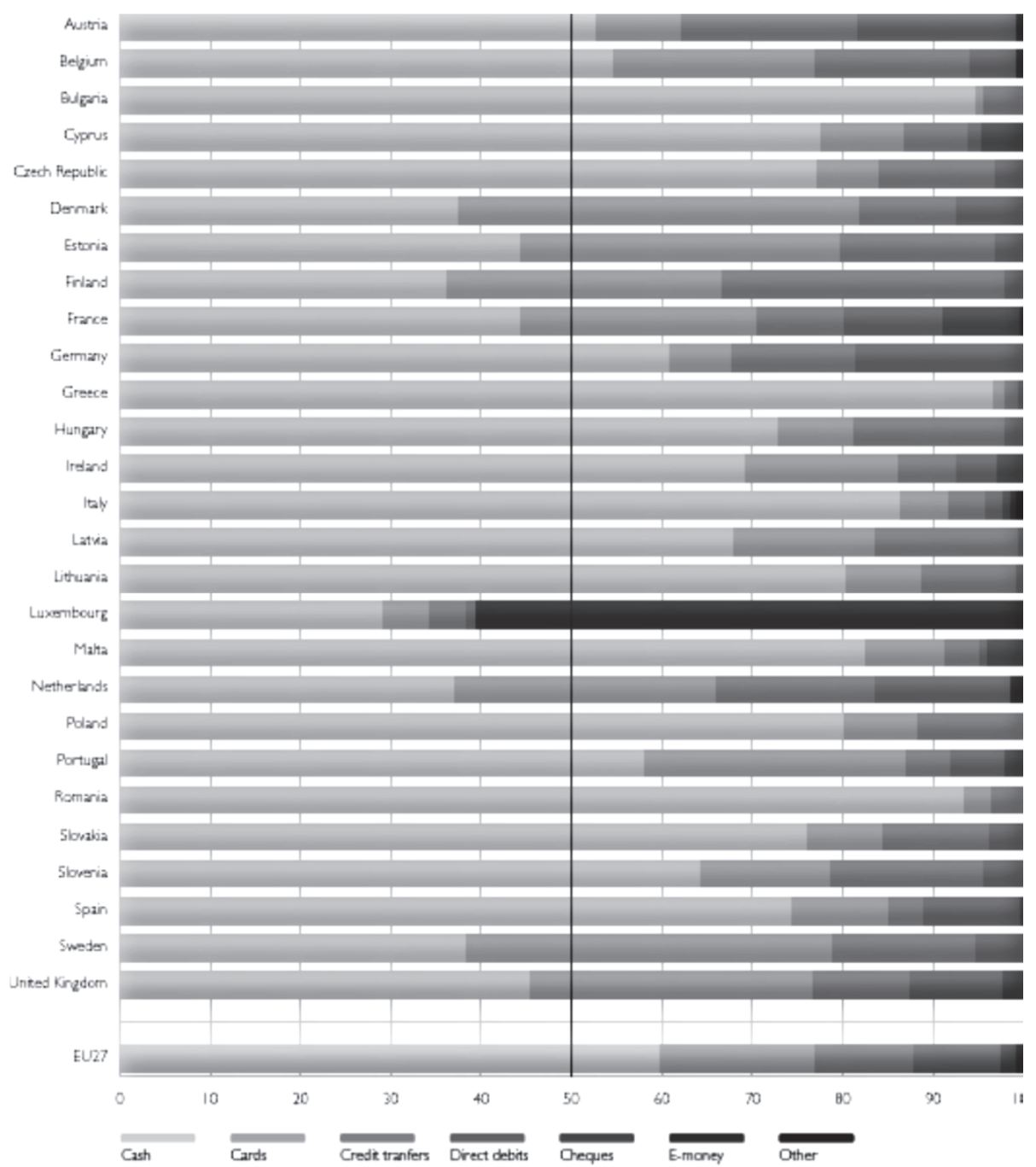

Figure 1. Payment instruments distribution: cash and non cash per country (EU27)

Source: G4S analysis based on ECB Statistics. The Social and Private Costs of Retail Payment Instruments. A European Perspective, H. Schmiedel, G. Kostova and W. Ruttenberg.

Various countries across Europe have set limits to the amount allowed to pay for in cash. These limits usually are used as measures against illegal and black market transactions. Also, the European Commission published on 2 February 2016 a Communication to the Council and the Parliament on an Action Plan to further step up the fight against the financing of terrorism (EC, 2016). In this context, the relevance of potential upper limits to cash payment could also be explored. Table 1 presents restrictions for using cash in transactions in 27 member states of the European Union. 
G. Gikas, A. Hyz, P. Tagkas, Abolishing cash in Europe: the benefits ...

Table 1. Restriction for using cash in transactions (EU27)

\begin{tabular}{|c|c|c|}
\hline Country & Cash Limit & Details \\
\hline Austria & No & - \\
\hline Belgium & Yes & 3,000 Euro for goods and all sorts of services \\
\hline Bulgaria & Yes & 14,999 Leva (about 7,670 Euro) \\
\hline Croatia & No & - \\
\hline Cyprus & No & - \\
\hline Czech Republic & Yes & 350,000 CZK per day (roughly 14,000 Euro or up to 50 coins \\
\hline Denmark & No & - \\
\hline Estonia & No & - \\
\hline Finland & No & $\begin{array}{l}\text { Cash can be denied as payment method if stated clearly before making } \\
\text { sale }\end{array}$ \\
\hline France & Yes & $\begin{array}{l}\text { 1,000 Euro for fiscal residents and 15,000 Euro for non-fiscal residents } \\
\text { acting as consumer. At government offices cash payment are restricted to } \\
300 \text { Euro. }\end{array}$ \\
\hline Germany & No & - \\
\hline Greece & Yes & Limited to 500 Euro \\
\hline Hungary & Yes & $\begin{array}{l}\text { No limit for consumers, but legal persons that are required to open a bank } \\
\text { account can only make payments up to } 1.5 \text { million HUF per month (about } \\
5,000 \text { Euro) }\end{array}$ \\
\hline Iceland & No & - \\
\hline Ireland & No & - \\
\hline Italy & Yes & Limited to 999.99 Euro \\
\hline Latvia & No & - \\
\hline Lithuania & No & - \\
\hline Luxembourg & No & - \\
\hline Malta & No & - \\
\hline Netherland & No & One can only withdraw once a day at ATMs owned by other banks \\
\hline Norway & No & - \\
\hline Poland & Yes & Limited to 15,000 Euro \\
\hline Portugal & Yes & $\begin{array}{l}\text { Any payment above } 1000 \text { Euro should be made in such a way that the } \\
\text { recipient can be identified }\end{array}$ \\
\hline Romania & Yes & Limited to 10,000 RON per day (about 2,260 Euro) \\
\hline Slovakia & Yes & Limited to 5,000 Euro \\
\hline Slovenia & No & - \\
\hline Spain & Yes & Limited to 2,500 Euro for residents and 15,000 Euro for non residents \\
\hline Sweden & No & Cash can be denied as payment means, if stated clearly before making sale \\
\hline United Kingdom & No & $\begin{array}{l}\text { Traders accepting cash payments of more than } € 15,000 \text { have to register as } \\
\text { 'High Value Dealer' with tax authorities }\end{array}$ \\
\hline
\end{tabular}

Source: European Consumer Centre France, https://www.europe-consommateurs.eu/en/consumer-topics/financialservices-insurance/banking/means-of-payment/cash-payment-limitations/ 


\section{The advantages of cash abolition}

The benefits most often mentioned by supporters of cash abolition are as follows:

- The abolition of cash transactions will contribute to the stability of the financial system, because if cash is eliminated, the possibility of panic among banks due to the massive withdrawal of deposits will be eliminated. Today, a bank's clients, if panicked, will massively withdraw their savings from it and can even force a healthy bank to bankruptcy. In the absence of cash, this problem will disappear.

- Electronic cash payments are cheaper and easier to use; additionally, they eliminate tons of paper money, money transfers, guards, as well as transportation and storage costs.

- Money laundering is also limited. This facilitates the fight against dirty money and corruption. The main way of trading in criminal activities is cash, so its absence can help combat these phenomena.

- The fight against the black economy (Gikas, 1992) and tax evasion is reinforced and governments are becoming more effective in combating these phenomena. Lack of cash is the end of "under the table" payments made in order to avoid taxes. Eliminating cash is a necessary measure to enhance citizens' tax compliance.

- On the other hand, cash abolition contributes to the fight against terrorism, which the monitoring of payments makes it easier to stop. Furthermore, the removal of high-denomination banknotes contributes to the fight against crime, given that their high value greatly facilitates the transfer of large sums of money in a relatively easy way, since the 500 euro banknotes are not too heavy, while they do not occupy much space either. The European Central Bank has therefore decided to discontinue the issuance of the EUR 500 banknote by the end of 2018, arguing that it can "facilitate illegal activities". However, the EUR 500 note will retain legal tender status and can therefore continue to be used as a payment instrument.

- This will then be the end of counterfeiting. Counterfeiters, from day to day, are bound to lose the object of their activity.

The above arguments dominate all the public debates on the subject and explain why governments and banks are in favor of cash elimination. However, in addition to all these advantages, there are many reservations and several risks associated with abolishing cash.

\section{The arguments against the elimination of cash}

The arguments against the elimination of cash include the following:

- Eliminating cash will inevitably lead to the end of the anonymity of transactions. It is total surveillance. Without coins and banknotes (cash) no transactions will be possible without leaving a trace; in contrast, cash transactions leave no electronic trace. 
- If cash is eliminated, mass outflows of deposits will be avoided when banks face difficulties. Households and businesses will constantly trust their "money” in banks, regardless of the risk of bankruptcy they may face, while they will only be able to withdraw it or spend it on another bank's account, even if there is a risk of bail-in (haircut). Bail-in means an impairment of the value of depositors' deposits for the consolidation of a bank. A typical example is that of Cyprus, where for the consolidation of its commercial banks, all deposits over 100,000 euros were cut in half.

- With the abolition of cash, household and business access to their money is restricted. All the money of the savers (Gikas, 1993) will necessarily be in bank accounts; in other words, locked up in bank accounts and under the constant threat of a possible financial crisis.

- The abolition of cash allows the monetary authorities to implement a policy of negative interest rates (Gikas, Hyz, 1993). Negative interest rates reduce the value of deposits; as a result, savers withdraw money from banks and keep it in cash in safe places, such as safe deposit boxes. Withdrawal of money can also stem from the savers' insecurity regarding the course of the economy and from the fear of deposits' "haircut". We can mention here, as a prime example, the recent financial crisis in Greece (Gikas, et al., 2012; Gikas, et al., 2013), where savers' fear of leaving the euro and suffering a haircut on their deposits led to massive withdrawals of their money from banks. The Greek monetary authorities, in order to protect the Greek banking system from a total collapse, were forced to impose capital controls.

- The elimination of cash also allows commercial banks to require account-maintenance fees. Negative interest rates and mandatory commissions reduce the actual and nominal value of depositors' deposits. If today, therefore, we had negative interest rates and the banks charged an account-maintenance fee, the savers would withdraw their money from the banking system and keep the banknotes "under the mattress" or in other secure places. This has happened in Greece with the recent financial crisis, though not for the above reasons, but due to the lack of depositors' confidence in the Greek banking system. In all banking systems, if the public loses confidence in banks, panic will prevail. Everyone will rush to withdraw their money from their bank accounts before the banks shut down.

- The growth of profits for electronic payment managers due to the increase in the volume of electronic transactions, at the expense of cash transactions, should also be mentioned. Financial service providers will also be able to require traders to pay higher commissions for electronic transactions.

- Counter-arguments also include the possibility of electronic blackout or cyber-attacks, which are likely to create enormous problems and chaos in economic activity.

- Electronic payments often lead to overspending phenomena (Sands, 2016, pp. 49$55)$, as citizens are proven to spend on average $30 \%$ more money than using cash. Europe's "sad eyes" in the portrait of euro banknotes often act as a deterrent to 
unnecessary costs. In cash purchases, the mental pressure is much higher, as we observe our money disappearing into the seller's drawer, which leads us to smarter purchases and increased savings.

- Less cash entails less revenue for central banks from their "seignorage” privilege and greater opportunities for commercial banks to create scriptural money ${ }^{5}$. By limiting cash in transactions, banks' liquidity will increase, as well as their ability to generate scriptural money. This increase, without sufficient bank supervision to protect against insolvency, can lead to an uncontrolled increase in credit and money supply. In periods of economic recession, borrowers are unable to service their debt in a timely manner. The volume of non-performing loans increases and banks face difficulties. Trust in their robustness is lost and a financial crisis breaks out.

- With a possible abolition of cash, commercial banks will invest far more openly in less liquid, higher-risk and high-yielding positions. They will no longer have a reason to fear that any temporary damage will cause panic and withdrawal of deposits that would lead to a lack of bank liquidity and bankruptcy. They will also not need to maintain sufficient liquidity to respond to mass outflows of their clients' deposits.

- Some economists and sociologists (Haring, 2016) believe that cash does not threaten our security and freedom; on the contrary, it contributes to safeguarding them, thus guaranteeing the last remnants of freedom and privacy left for us. Cash limits the deprivation of our rights, as well as the control and monitoring by various agencies and the financial sector, including the collection of personal data by the IT industry. Electronic transactions can give away all the information about us. Monitoring users over the internet has become inevitable. Extensive transaction controls are performed both for legitimate reasons, such as crime prevention, and for less respectable, such as data collection by commercial companies. If cash disappears, we will have a form of real-time, complete monitoring. Then there will be an analytical profile of transactions, as there are not many things that can be done without making payments, even occasionally. If cash is eliminated, many economists talk about a creepy scenario where privacy laws are being circumvented.

The arguments expressed by supporters of cash elimination, nevertheless, are based on the principle that people who do not do anything illegal or inappropriate do not need privacy and personal data protection, while others do not even deserve it.

\footnotetext{
${ }^{5}$ Scriptural money (Gikas, Hyz, 2016) is created by commercial banks through successive credits. It is a liability - the bank's debt to the depositor, who can terminate the loan agreement with the bank at any time, by withdrawing his or her deposit in the form of cash. In contrast, coins and banknotes (cash) are produced by the state through the central bank and are legal tender, while no one can deny them as a means of payment. They are recorded as a liability in the liabilities of the central bank's balance sheet, but they are not a material obligation or debt, since anyone who presents this debt to the central bank will receive cash again.
} 


\section{Conclusions}

Ever since the dawn of money, people have explored the advantages and disadvantages of different means of payment. Taking into account the changes that have taken place over the last few years, the problem of efficient and acceptable methods of payment from an economic and social point of view becomes more and more interesting. An efficient payment system is not an end in itself, but a necessary precondition for fostering national and international wellbeing. Consequently, the discussion may derive outcomes that are both of relevance to policy-making and of interest to the parties involved in the payment cycle.

Payment systems are exposed to change through innovations in finance and payment transactions, technological changes, legal restrictions, as well as through changes in the payment habits of consumers. In this paper we tried to analyze the problem of cash abolition.

What is the future of cash as a payment instrument? Will electronic payments completely replace cash? Will we have a truly cashless society? Till now, cash is still present in our society as a legal means of payment and cash transactions represent over $50 \%$ of all payment transactions in the European Union and vary widely across member states. Non-cash transaction volumes, especially card transactions, seem to grow faster, resulting in a diminishing share of cash in the total transaction volume. In most of the European Union's countries cash payments are limited by law or limited by practice. Last year, the European Commission announced its intention to explore the relevance of potential upper limits to cash payments. Some of the crucial factors which drive cash abolition and the diffusion of digital money are: lower transaction costs, less crime, and easier collection of taxes. However, there are many reservations and several risks associated with abolishing cash which have to be seriously taken into account.

\section{References}

Gikas, G., Hyz, A., Tagkas, P. (2012). Global Financial Crisis and Greek Debt Crisis, Acta Universitatis Lodziensis. Folia Oeconomica, nr 273.

Gikas, G. (1992). Przyczyny i konsekwencje gospodarki drugiego obiegu. Gospodarka Narodowa, No 9.

Gikas, G. (1992). Teoria i polityka bodżcow podatkowych. Bank i Kredyt, № 7-8.

Gikas, G., Hyz, A. (1993). Stopa procentowa a podaż kredytow i deficyt sektora publicznego. Bank i Kredyt, No 2.

Gikas, G., Hyz, A., Tagkas, P. (2013). The Experience of Greece from its participation in the Eurozone. Management Insight, The Journal of Incisive Analysers, Vol. IX, No. 1; June 2013.

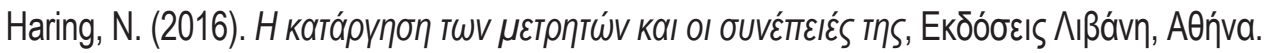
Hyz, A., Gikas, G. (1993). Kształtowanie poziomu oszczędności gospodarstw domowych. Bank i Kredyt, No 7. 
Sands, P. (2016). „Making in Harder for the Bad Guys: The Case for Eliminating High Denomination Notes". Associate Working Paper Series, nr 52.

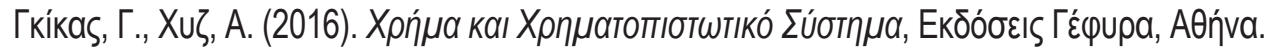

G4S, Cash Report. Europe, 2016.

Report on the Role of Cash in Society.

Garcia-Swartz, D.D., Hahn R.W., Layne-Farrar, A. (2004). The Economics of a Cashless Society: an Analysis of the Costs and Benefits of Payment Instruments., Working Paper 04-24, AEIBrookings Joint Center for Regulatory Studies.

Garcia-Swartz, D.D., Hahn, R.W., Layne-Farrar, A. (2006a). The Move Toward a Cashless Society: A Closer Look at Payment Instrument Economics. Review of Network Economics 5, pp. 175-197.

Garcia-Swartz, D.D., Hahn, R.W, Layne-Farrar, A. (2006b). The Move Toward a Cashless Society: Calculating the Costs and Benefits. Review of Network Economics 5, pp. 198-228.

Arango, C., Taylor, V. (2008). „Merchant Acceptance, Costs, and Perceptions of Retail Payments: A Canadian Survey". Bank of Canada Discussion Paper No. 2008-12.

Bergman, M., Guibourg, G., and Segendorf, B. (2007). The Costs of Paying-Private and Social Costs of Cash and Card. Sveriges Riksbank Working Paper Series No. 212.

OECD, (2002). The Future of Money. 